Utah State University

DigitalCommons@USU

\title{
An Equitable, Efficient and Implementable Scheme to Control Global Carbon Dioxide Emissions
}

Arthur J. Kaplan

Utah State University

Emilson C.D. Silva

Follow this and additional works at: https://digitalcommons.usu.edu/eri

\section{Recommended Citation}

Kaplan, Arthur J. and Silva, Emilson C.D., "An Equitable, Efficient and Implementable Scheme to Control Global Carbon Dioxide Emissions" (2002). Economic Research Institute Study Papers. Paper 255.

https://digitalcommons.usu.edu/eri/255

This Article is brought to you for free and open access by the Economics and Finance at DigitalCommons@USU. It has been accepted for inclusion in Economic Research Institute Study Papers by an authorized administrator of DigitalCommons@USU. For more information, please contact digitalcommons@usu.edu.

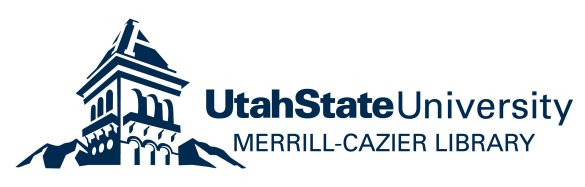


Economic Research Institute Study Paper

ERI \#2002-22

\title{
AN EQUITABLE, EFFICIENT AND IMPLEMENTABLE SCHEME TO CONTROL GLOBAL CARBON DIOXIDE EMISSIONS
}

\author{
by \\ ARTHUR J. CAPLAN \\ Department of Economics \\ Utah State University \\ 3530 Old Main Hill \\ Logan, UT 84322-3530 \\ EMILSON C.D. SILVA \\ Department of Economics \\ Tulane University \\ New Orleans, LA 70118-5698
}

December 2002 


\title{
AN EQUITABLE, EFFICIENT AND IMPLEMENTABLE SCHEME TO CONTROL GLOBAL CARBON DIOXIDE EMISSIONS
}

\author{
Arthur J. Caplan, Assistant Professor \\ Department of Economics \\ Utah State University \\ 3530 Old Main Hill \\ Logan, UT 84322-3530 \\ Emilson C.D. Silva \\ Department of Economics \\ Tulane University \\ New Orleans, LA 70118-5698
}

The analyses and views reported in this paper are those of the author(s). They are not necessarily endorsed by the Department of Economics or by Utah State University.

Utah State University is committed to the policy that all persons shall have equal access to its programs and employment without regard to race, color, creed, religion, national origin, sex, age, marital status, disability, public assistance status, veteran status, or sexual orientation.

Information on other titles in this series may be obtained from: Department of Economics, Utah State University, 3530 Old Main Hill, Logan, UT 84322-3530.

Copyright ( 92003 by Arthur J. Caplan and Emilson C.D. Silva. All rights reserved. Readers may make verbatim copies of this document for noncommercial purposes by any means, provided that this copyright notice appears on all such copies. 


\title{
AN EQUITABLE, EFFICIENT AND IMPLEMENTABLE SCHEME \\ TO CONTROL GLOBAL CARBON DIOXIDE EMISSIONS
}

Arthur J. Caplan and Emilson C.D. Silva

\begin{abstract}
We design an international scheme to control global carbon dioxide emissions in which autonomous developed and developing regions choose their own carbon dioxide emissions in anticipation of interregional resource transfers to be implemented by an international agency. This agency's objective function obeys a proportional equity principle, which preserves the status-quo relative ranking of regional welfare levels. We show that it is individually rational for each region to participate in our proposed international scheme and that regional environmental authorities choose policies that internalize the global environmental externalities. These results are especially noteworthy in light of the call for international transfers from developed to developing countries in the Kyoto Protocol.

JEL classification: 72, D62, D78, H41, H77, Q28
\end{abstract}




\section{AN EQUITABLE, EFFICIENT AND IMPLEMENTABLE SCHEME TO CONTROL GLOBAL CARBON DIOXIDE EMISSIONS}

\section{Introduction}

The Kyoto Protocol to the United Nations Framework Convention on Climate Change (called “Convention" hereafter), completed on December 10, 1997, will probably be remembered most for selecting emissions trading as the main mechanism to control global greenhouse gas emissions. However, it will also be remembered for the promulgation of another type of incentive: international transfers between developed and developing regions. These transfers are intended to: (1) "provide new and additional financial resources to meet agreed full costs incurred by (developing) countries in advancing the implementation of existing commitments;" and (2) "provide such financial resources, including for the transfer of technology, needed by (developing) countries to meet the agreed full incremental costs of advancing the implementation of existing commitments" (Article 12 of the protocol). The Conference of the Parties to the Convention, the Convention's supreme body, delegated to the Global Environment Facility (GEF) the responsibility of transferring resources from developed to developing regions.

In this paper, we investigate the efficiency and implementability properties of an international scheme designed to control global carbon dioxide emissions. In our proposed scheme, the participating regions select their most desirable carbon dioxide emission quantities fully anticipating that an international agency, say the GEF, will implement resource transfers from developed to developing regions in accordance with a particular equity principle. We demonstrate that if the GEF's objective function obeys a proportional equity principle, which preserves the status-quo relative ranking of international welfare levels, both developed and developing regions have incentives to: (1) voluntarily participate in the international scheme; and 
(2) efficiently control their carbon dioxide emissions. The equilibrium allocation of resources for the global economy in the presence of the international scheme is proportionally equitable and Pareto efficient.

Intuitively, the resource transfers promoted by the GEF align the incentives of the participating regions because the welfare of one region can rise only if the welfare of the other region rises. Since the autonomous regional governments are aware of this fact when they select their most desirable levels of carbon dioxide emission, they have incentives to choose regional environmental policies that internalize the global externalities. Previous works (see, e.g., Boadway (1982), Caplan and Silva (1999), Myers (1990), Silva (1997), Silva and Caplan (1997), Nagase and Silva (2000) and Wellisch (1994)) have shown that competing autonomous regional governments may behave efficiently when they anticipate that regional welfare levels will be equalized in equilibrium. Myers (1990) referred to this phenomenon as "perfect incentive equivalence." This literature typically considers resource allocation problems in federations that have already been formed and, therefore, tend to neglect participation decisions.

Our paper makes two significant contributions to this literature. First, we explicitly consider participation constraints and show that it is always individually desirable for each region to participate in the international scheme. This "implementability" result is novel. Second, we demonstrate that equalization of regional welfare levels is not necessary for perfect incentive equivalence. We obtain perfect incentive equivalence because the welfare levels of competing autonomous regional governments are positively related (i.e., they are complements) in equilibrium. This "efficiency" result is also novel.

Although the focus of our analysis is not on emissions trading, this paper is closely related to the emerging literature on environmental markets. Chichilnisky, et al. (2000), for 
example, show that equity and efficiency go hand in hand whenever carbon dioxide emissions are traded. They demonstrate that emission markets will allocate resources efficiently if and only if international transfers are made in order to equalize social marginal utilities of consumption. They also show that this resource redistribution condition can be satisfied by an appropriate initial distribution of emission permits.

Our analysis provides support for this recent view that equity and efficiency play complementary roles in a "solution" to the global warming problem. Our results suggest that it is possible to achieve efficiency only if international transfers are promoted to advance some equity principle. In our framework, the GEF's optimal strategy entails equalization of social marginal utilities of consumption in equilibrium. But, unlike in Chichilnisky, et al. (2000), the resource redistribution takes place after the autonomous regional governments select their most desirable emission quantities. Indeed, it is this sequencing of moves that induces efficient behavior in the absence of a global market for carbon emissions.

\section{The Model}

Consider an economy consisting of two regions indexed by $\mathrm{j}, \mathrm{j}=1,2$. Throughout, the reader is invited to think of regions 1 and 2 as the globe's developed and developing regions, respectively. Each region has an autonomous government. There are two marketed commodities, a commodity whose production results in emission of carbon dioxide (e.g., an industrial good) and a commodity whose production is harmed by emissions of carbon dioxide (e.g., an agricultural good). Let $\mathrm{X}_{\mathrm{j}}$ be region $\mathrm{j}$ 's industrial product and $\mathrm{E}$ be the total quantity of carbon dioxide emitted in the atmosphere. We assume that $\mathrm{E} \equiv \mathrm{X}_{1}+\mathrm{X}_{2}$; that is, production of a unit of the industrial good leads to the emission of a unit of carbon dioxide. 
The industrial sector in region $\mathrm{j}$ is competitive and consists of a large number of identical producers. Let $k_{j}$ be the (fixed) number of industrial producers in region $\mathrm{j}$. Each industrial producer utilizes an input quantity $z_{\mathrm{Yj}_{\mathrm{j}}} \leq 0$ of the agricultural good to produce $\mathrm{f}^{\mathrm{j}}\left(\mathrm{z}_{\mathrm{Y}_{\mathrm{j}}}\right)$ units of the industrial good. We assume that $\mathrm{f}^{\mathrm{j}}$ is decreasing and strictly concave. Define $Z_{\mathrm{Yj}_{\mathrm{j}}} \equiv \mathrm{k}_{\mathrm{j}} \mathrm{Z}_{\mathrm{Yj}}$ as the total amount of the agricultural good demanded as input by region j's industrial sector and $\mathrm{F}^{\mathrm{j}}\left(\mathrm{Z}_{\mathrm{Yj}}\right) \equiv \mathrm{k}_{\mathrm{j}} \mathrm{f}^{\mathrm{j}}\left(\mathrm{Z}_{\mathrm{y}_{\mathrm{j}}} / \mathrm{k}_{\mathrm{j}}\right)$ as this sector's production function. Hence, $\mathrm{X}_{\mathrm{j}}=\mathrm{F}^{\mathrm{j}}\left(\mathrm{Z}_{\mathrm{y}_{\mathrm{j}}}\right)$. If we let $\mathrm{p}_{\mathrm{x}}$ and $\mathrm{p}_{\mathrm{Y}}$ denote the prices of the industrial and agricultural goods, respectively, the profit of the industrial sector in region $j$ is $p_{x} X_{j}+p_{y} Z_{y_{j}}$.

The agricultural sector in region $\mathrm{j}$ is also competitive. Let $\mathrm{m}_{\mathrm{j}}$ be region $\mathrm{j}$ 's (fixed) number of agricultural producers. Each agricultural producer utilizes an input quantity $\mathrm{z}_{\mathrm{xj}} \leq 0$ of the industrial good to produce $\mathrm{g}^{\mathrm{j}}\left(\mathrm{z}_{\mathrm{x}}, \mathrm{E}\right)$ units of the agricultural good. We assume that $\mathrm{g}^{\mathrm{j}}$ is decreasing in both arguments and strictly concave. Define $Z_{\mathrm{xj}} \equiv \mathrm{m}_{\mathrm{j}} \mathrm{z}_{\mathrm{xj}}$ and $G^{j}\left(Z_{x_{j}}, \sum_{i=1}^{2} F^{i}\left(Z_{Y_{i}}\right)\right) \equiv m_{j} g^{j}\left(Z_{x j} / m_{j}, \sum_{i=1}^{2} F^{i}\left(Z_{Y_{i}}\right)\right)$. Let $Y_{j}=G^{j}\left(Z_{x j}, \sum_{i=1}^{2} F^{i}\left(Z_{Y_{i}}\right)\right)$ be region $j$ 's agricultural product. Then, this sector's profit is $\mathrm{p}_{\mathrm{Y}} \mathrm{Y}_{\mathrm{j}}+\mathrm{p}_{\mathrm{x}} Z_{\mathrm{xj}}$.

Region $\mathrm{j}$ has a large population $\mathrm{n}_{\mathrm{j}}$ of identical residents. The utility of each consumer in region $\mathrm{j}$ is $\mathrm{U}^{\mathrm{j}}\left(\mathrm{x}_{\mathrm{j}}, \mathrm{y}_{\mathrm{j}}, \mathrm{E}\right)$, where $\mathrm{x}_{\mathrm{j}}$ and $\mathrm{y}_{\mathrm{j}}$ are the quantities consumed of the industrial and agricultural goods, respectively. We assume that $\mathrm{U}^{\mathrm{j}}$ is strictly quasiconcave. It increases in the first two arguments and decreases in the last. Carbon dioxide emissions are, therefore, harmful to each individual's welfare.

Let $I_{j} \equiv p_{X} X_{j}^{0}+p_{Y} Y_{j}^{0}+p_{x} X_{j}+p_{Y} Z_{Y j}+p_{Y} Y_{j}+p_{X} Z_{X j}+T_{j}$ be region $j$ 's total income. The quantities $\mathrm{X}_{\mathrm{j}}^{0}$ and $\mathrm{Y}_{\mathrm{j}}^{0}$ denote region $\mathrm{j}$ 's initial endowments of industrial and agricultural goods, 
respectively. The quantity $T_{j}$ represents the total amount of income that this region receives from the other region (if positive) or remits to the other region (if negative) in order to satisfy the proportional equity principle underlying the international scheme examined below. Since the interregional transfers are purely redistributive, $T_{1}+T_{2}=0$. Each consumer in region $\mathrm{j}$ faces a budget constraint $\mathrm{p}_{\mathrm{x}} \mathrm{x}_{\mathrm{j}}+\mathrm{p}_{\mathrm{y}} \mathrm{y}_{\mathrm{j}}=\mathrm{I}_{\mathrm{j}} / \mathrm{n}_{\mathrm{j}}$.

Both industrial and agricultural goods are freely traded in international markets. In any equilibrium for the global economy, $\sum_{j=1}^{2}\left(n_{j} x_{j}-X_{j}^{0}-X_{j}-Z_{X_{j}}\right)=0$ and $\sum_{j=1}^{2}\left(n_{j} y_{j}-Y_{j}^{0}-Y_{j}-Z_{Y_{j}}\right)=0$; namely, the international markets must clear. To keep things simple, we henceforth normalize the price of the agricultural good to one. This normalization will enable us to ignore the market clearing condition for the agricultural good, since it is automatically satisfied whenever the other conditions that characterize an equilibrium allocation are satisfied. The normalization also allows us to set $\mathrm{p}_{\mathrm{x}} \equiv \mathrm{p}$.

\section{Pareto Efficiency}

Before we analyze the making of environmental policy, it is useful to consider the conditions that characterize a Pareto efficient allocation. A Pareto efficient allocation can be obtained by choosing $\left\{\mathrm{x}_{\mathrm{j}}, \mathrm{y}_{\mathrm{j}}, \mathrm{X}_{\mathrm{j}}, \mathrm{Y}_{\mathrm{j}}, \mathrm{Z}_{\mathrm{x}}, \mathrm{Z}_{\mathrm{y}_{\mathrm{j}}}\right\}_{\mathrm{j}=1,2}$ to maximize $\mathrm{U}^{1}\left(\mathrm{x}_{1}, \mathrm{y}_{\mathrm{l}}, \mathrm{X}_{1}+\mathrm{X}_{2}\right)$ subject to:

$$
\begin{aligned}
& \mathrm{U}^{2}\left(\mathrm{x}_{2}, \mathrm{y}_{2}, \mathrm{X}_{1}+\mathrm{X}_{2}\right) \geq \overline{\mathrm{U}}^{2} \text { and } \\
& X_{j} \leq F^{j}\left(Z_{Y_{j}}\right), Y_{j} \leq G^{j}\left(Z_{X j}, \sum_{i=1}^{2} F^{i}\left(Z_{Y_{i}}\right)\right), \sum_{j=1}^{2}\left(n_{j} X_{j}-X_{j}^{0}-X_{j}-Z_{X j}\right) \leq 0, \sum_{j=1}^{2}\left(n_{j} y_{j}-Y_{j}^{0}-Y_{j}-Z_{Y_{j}}\right) \leq 0, \\
& x_{j} \geq 0, y_{j} \geq 0, X_{j} \geq 0, Y_{j} \geq 0, Z_{x j} \leq 0, Z_{\gamma_{j}} \leq 0, j=1,2 .
\end{aligned}
$$

An interior Pareto efficient allocation satisfies:

$$
\mathrm{U}^{2}\left(\mathrm{x}_{2}, \mathrm{y}_{2}, \mathrm{X}_{1}+\mathrm{X}_{2}\right)=\overline{\mathrm{U}}^{2}>0,
$$




$$
\begin{aligned}
& X_{j}=F^{j}\left(Z_{Y_{j}}\right)>0, Y_{j}=G^{j}\left(Z_{x j}, \sum_{i=1}^{2} F^{i}\left(Z_{Y_{i}}\right)\right)>0, j=1,2, \\
& \sum_{j=1}^{2}\left(n_{j} X_{j}-X_{j}^{0}-X_{j}-Z_{x_{j}}\right)=0, \sum_{j=1}^{2}\left(n_{j} y_{j}-Y_{j}^{0}-Y_{j}-Z_{Y_{j}}\right)=0, \\
& \frac{U_{x}^{1}}{U_{y}^{1}}=\frac{U_{x}^{2}}{U_{y}^{2}}>0, \\
& \frac{U_{x}^{j}}{U_{y}^{j}}=-G_{z}^{j}=-\frac{1}{F_{z}^{j}}-\sum_{i=1}^{2}\left(n_{i} \frac{U_{E}^{i}}{U_{y}^{i}}+G_{E}^{i}\right), j=1,2 .
\end{aligned}
$$

Conditions (1a)-(1d) require no comment because they are fairly standard. The first equality in equations (1e) tells us that the marginal rate of substitution between industrial and agricultural goods for the representative consumer of region $\mathrm{j}$ must be equal to region $\mathrm{j}$ 's marginal cost of agricultural production. The second equality informs us that this marginal cost must be equal to region j's social marginal rate of transformation between industrial and agricultural goods, which includes the global marginal negative effects brought upon by production of the industrial good in the region. From equations (1d) and (1e), it follows that $G_{z}^{1}=G_{z}^{2}$ and $F_{z}^{1}=F_{z}^{2}$; that is, we observe equalization of marginal products for each good.

\section{Environmental Policy Making}

Remember that the amount of carbon dioxide emitted in a region corresponds to the regional quantity of the industrial good produced. Then, it is reasonable to think that each regional government regulates the regional industrial product. Since, in our model, having control over a region's industrial product is equivalent to having control over a region's quantity of input demanded by the industrial sector, the policy instrument controlled by the regulator in region $\mathrm{j}$ is $Z_{\mathrm{y} j}$. Regional regulators make their policy choices knowing how the other regional 
agents will behave. As such, it becomes imperative that we first consider the problems facing agricultural producers and consumers.

In region $\mathrm{j}$, the agricultural sector chooses non-positive $\left\{\mathrm{Z}_{\mathrm{xj}}\right\}$ to maximize $\mathrm{G}^{\mathrm{j}}\left(\mathrm{Z}_{\mathrm{xj}}, \mathrm{E}\right)+\mathrm{pZ} \mathrm{Z}_{\mathrm{xj}}$ taking $\left\{p, Z_{x-j}, E\right\}$ as given. This notation tells us that $-j=1$ if $j=2$ and $-j=2$ if $j=1$. An interior solution satisfies $G_{z}^{j}+p=0$. Let $Z_{x_{j}}(p, E)$ and $\Pi^{\mathrm{vj}}(\mathrm{p}, \mathrm{E}) \equiv \mathrm{G}^{\mathrm{j}}\left(\mathrm{Z}_{\mathrm{xj}}(\mathrm{p}, \mathrm{E}), \mathrm{E}\right)+\mathrm{p} Z_{\mathrm{xj}}(\mathrm{p}, \mathrm{E})$ denote the agricultural sector's input-demand and indirect-profit functions, respectively. For future reference, let $Z_{\mathrm{Xj}}\left(\mathrm{p}, Z_{\mathrm{Y} 1}, Z_{\mathrm{Y} 2}\right) \equiv Z_{\mathrm{x} j}\left(\mathrm{p}, \sum_{\mathrm{i}=1}^{2} \mathrm{~F}^{\mathrm{i}}\left(\mathrm{Z}_{\mathrm{Yi}}\right)\right)$ and $\Pi^{\mathrm{Yj}}\left(\mathrm{p}, Z_{\mathrm{Y} 1}, Z_{\mathrm{Y} 2}\right) \equiv \Pi^{\mathrm{Yj}}\left(\mathrm{p}, \sum_{\mathrm{i}=1}^{2} \mathrm{~F}^{\mathrm{i}}\left(\mathrm{Z}_{\mathrm{Yi}}\right)\right)$. Note that $\partial \Pi^{\mathrm{Yj}} / \partial \mathrm{p} \equiv \mathrm{Z}_{\mathrm{xj}}<0, \partial \Pi^{\mathrm{Yj}} / \partial \mathrm{Z}_{\mathrm{Yj}_{\mathrm{j}}} \equiv \mathrm{G}_{\mathrm{E}}^{\mathrm{j}} \mathrm{F}_{\mathrm{Z}}^{\mathrm{j}}>0, \partial \Pi^{\mathrm{Yj}} / \partial \mathrm{Z}_{\mathrm{Y}-\mathrm{j}} \equiv \mathrm{G}_{\mathrm{E}}^{\mathrm{j}} \mathrm{F}_{\mathrm{Z}}^{-\mathrm{j}}>0$.

Each consumer in region $\mathrm{j}$ chooses nonnegative $\left\{\mathrm{x}_{\mathrm{j}}, \mathrm{y}_{\mathrm{j}}\right\}$ to maximize $\mathrm{U}^{\mathrm{j}}\left(\mathrm{x}_{\mathrm{j}}, \mathrm{y}_{\mathrm{j}}, \mathrm{E}\right)$ s.t. $\mathrm{px}_{\mathrm{j}}+\mathrm{y}_{\mathrm{j}}=\mathrm{I}_{\mathrm{j}} / \mathrm{n}_{\mathrm{j}}$, taking $\left\{\mathrm{p}, \mathrm{I}_{\mathrm{j}}, \mathrm{E}\right\}$ as given. An interior solution satisfies the budget constraint and $\mathrm{U}_{\mathrm{x}}^{\mathrm{j}} / \mathrm{U}_{\mathrm{y}}^{\mathrm{j}}=\mathrm{p}$. Let $\mathrm{x}_{\mathrm{j}}\left(\mathrm{p}, \mathrm{I}_{\mathrm{j}}, \mathrm{E}\right)$ and $\mathrm{y}_{\mathrm{j}}\left(\mathrm{p}, \mathrm{I}_{\mathrm{j}}, \mathrm{E}\right)$ be the consumer's demand functions. It is convenient, however, to express these demands as functions of the policy variables and the industrial good's price:

$$
\begin{aligned}
& x_{j}\left(p, Z_{Y 1}, Z_{Y 2}, T_{j}\right) \equiv x_{j}\left(p, Y_{j}^{0}+p X_{j}^{0}+T_{j}+p F^{j}\left(Z_{Y_{j}}\right)+Z_{Y_{j}}+\Pi^{\gamma_{j}}\left(p, Z_{Y_{1}}, Z_{Y_{2}}\right), \sum_{i=1}^{2} F^{i}\left(Z_{Y i}\right)\right), \\
& y_{j}\left(p, Z_{Y 1}, Z_{Y 2}, T_{j}\right) \equiv y_{j}\left(p, Y_{j}^{0}+p X_{j}^{0}+T_{j}+p F^{j}\left(Z_{Y_{j}}\right)+Z_{Y_{j}}+\Pi^{\gamma_{j}}\left(p, Z_{Y 1}, Z_{Y 2}\right), \sum_{i=1}^{2} F^{i}\left(Z_{Y i}\right)\right) .
\end{aligned}
$$

Let $\mathrm{V}^{\mathrm{j}}\left(\mathrm{p}, \mathrm{Z}_{\mathrm{Y} 1}, \mathrm{Z}_{\mathrm{Y} 2}, \mathrm{~T}_{\mathrm{j}}\right) \equiv \mathrm{U}^{\mathrm{j}}\left(\mathrm{x}_{\mathrm{j}}\left(\mathrm{p}, \mathrm{Z}_{\mathrm{Y} 1}, \mathrm{Z}_{\mathrm{Y} 2}, \mathrm{~T}_{\mathrm{j}}\right), \mathrm{y}_{\mathrm{j}}\left(\mathrm{p}, \mathrm{Z}_{\mathrm{Y} 1}, \mathrm{Z}_{\mathrm{Y} 2}, \mathrm{~T}_{\mathrm{j}}\right), \sum_{\mathrm{i}=1}^{2} \mathrm{~F}^{\mathrm{i}}\left(\mathrm{Z}_{\mathrm{Yi}}\right)\right)$ be the consumer's indirect utility function. Given (2), we obtain:

$$
\begin{array}{r}
\partial V^{j} / \partial p \equiv\left(X_{j}^{0}+X_{j}+Z_{x j}-n_{j} X_{j}\right)\left(U_{y}^{j} / n_{j}\right), \\
\partial V^{j} / \partial Z_{Y j} \equiv U_{E}^{j} F_{Z}^{j}+\left(p F_{Z}^{j}+1+G_{E}^{j} F_{Z}^{j}\right)\left(U_{y}^{j} / n_{j}\right), \\
\partial V^{j} / \partial Z_{Y-j} \equiv U_{E}^{j} F_{Z}^{j}+G_{E}^{j} F_{Z}^{-j}\left(U_{y}^{j} / n_{j}\right)>0,
\end{array}
$$




$$
\partial V^{j} / \partial T_{j} \equiv U_{y}^{j} / n_{j}>0 .
$$

The market clearing condition for the industrial good can now be written as follows:

$$
\sum_{j=1}^{2} n_{j} x_{j}\left(p, Z_{Y 1}, Z_{Y_{2}}, T_{j}\right)=\sum_{j=1}^{2}\left(X_{j}^{0}+F^{j}\left(Z_{Y_{j}}\right)+Z_{x j}\left(p, Z_{Y 1}, Z_{Y 2}\right)\right) .
$$

Regional regulators control the input quantities demanded by the regional industrial sectors, but not the regional input quantities of the industrial good used in the production of the agricultural good. The market clearing condition for the industrial good can be used to implicitly define $\mathrm{p}\left(\mathrm{Z}_{\mathrm{Y} 1}, \mathrm{Z}_{\mathrm{Y} 2}, \mathrm{~T}_{1}, \mathrm{~T}_{2}\right)$. As we pointed out in section 2 above, we can ignore the market clearing condition for the agricultural good.

We examine environmental policy making in two policy settings, one in which both regions participate in the international scheme to control global carbon dioxide emissions and another in which there is no international scheme. When both regions participate in the scheme, they do so voluntarily. Therefore, each region's utility from participation must be no less than its utility from nonparticipation (i.e., its reservation utility). Since these participation constraints can be adequately written only after we compute the reservation utilities, we first consider the setting in which there is no international scheme.

\subsection{The Decentralized Policy Game}

While it is reasonable to assume that individual producers and consumers are price takers, it is equally reasonable to assume that the regional regulators are endowed with considerable market power. Hence, regulator $j$ chooses non-positive $\left\{Z_{\mathrm{Y}_{j}}\right\}$ to maximize $\mathrm{V}^{\mathrm{j}}\left(\mathrm{p}, \mathrm{Z}_{\mathrm{Y} 1}, Z_{\mathrm{Y}_{2}}\right)$ s.t. 
$\mathrm{p}=\mathrm{p}\left(\mathrm{Z}_{\mathrm{Y} 1}, \mathrm{Z}_{\mathrm{Y} 2}\right)$, taking $\left\{\mathrm{Z}_{\mathrm{Y}-\mathrm{j}}\right\}$ as given, $\mathrm{j}=1,2 .{ }^{1}$ Assuming interior solutions, the first order conditions are

$$
\frac{\partial \mathrm{V}^{\mathrm{j}}}{\partial \mathrm{p}} \frac{\partial \mathrm{p}}{\partial \mathrm{Z}_{\mathrm{Yj}}}+\frac{\partial \mathrm{V}^{\mathrm{j}}}{\partial \mathrm{Z}_{\mathrm{Yj}}}=0, \mathrm{j}=1,2
$$

Given (3a), (3b) and $U_{x}^{j} / U_{y}^{j}=p$, we may rewrite equations (4) as follows:

$$
\frac{U_{x}^{j}}{U_{y}^{j}}=-\left[1+\left(X_{j}^{0}+X_{j}+Z_{x j}-n_{j} x_{j}\right)\left(\frac{\partial p}{\partial Z_{y_{j}}}\right)\right]\left(\frac{1}{F_{Z}^{j}}\right)-n_{j} \frac{U_{E}^{j}}{U_{y}^{j}}-G_{E}^{j}, j=1,2,
$$

where

$$
\frac{\partial p}{\partial Z_{Y_{j}}} \equiv \frac{\mathrm{F}_{\mathrm{Z}}^{\mathrm{j}}+\sum_{\mathrm{i}=1}^{2} \frac{\partial \mathrm{Z}_{\mathrm{Xi}}}{\partial \mathrm{Z}_{\mathrm{Yj}}}}{\sum_{\mathrm{i}=1}^{2}\left(\mathrm{n}_{\mathrm{i}} \frac{\partial \mathrm{x}_{\mathrm{i}}}{\partial \mathrm{p}}-\frac{\partial \mathrm{Z}_{\mathrm{xi}}}{\partial \mathrm{p}}\right)}-\frac{\sum_{\mathrm{i}=1}^{2} \mathrm{n}_{\mathrm{i}} \frac{\partial \mathrm{x}_{\mathrm{i}}}{\partial \mathrm{Z}_{\mathrm{Yj}}}}{\sum_{\mathrm{i}=1}^{2}\left(\mathrm{n}_{\mathrm{i}} \frac{\partial \mathrm{x}_{\mathrm{i}}}{\partial \mathrm{p}}-\frac{\partial \mathrm{Z}_{\mathrm{Xi}}}{\partial \mathrm{p}}\right)}, \mathrm{j}=1,2,
$$

follows from differentiation of the market clearing condition for the industrial good. Comparing equations (5) with equations (1e), we notice that the decentralized policy equilibrium involves two sources of distortion, an "externality" distortion and a "market power" distortion. The externality distortion comes from the fact that each regulator ignores the negative effects that his region's production of the industrial good generates in the other region. The market power distortion arises because each regulator's choice influences the price of the industrial good and hence the international terms of trade. As equations (6) clearly illustrate, the market power distortion consists of two components. The first is the marginal effect on the net global supply of the industrial good originating with regulator j's market intervention. The second is the marginal effect on the global demand of the industrial good caused by such an intervention. Although the net effect is not nil in general, it cannot be unambiguously signed.

$$
{ }^{1} \mathrm{~V}^{\mathrm{j}}\left(\mathrm{p}, \mathrm{Z}_{\mathrm{Y} 1}, \mathrm{Z}_{\mathrm{Y} 2}\right) \equiv\left\{\mathrm{V}^{\mathrm{j}}\left(\mathrm{p}, \mathrm{Z}_{\mathrm{Y} 1}, \mathrm{Z}_{\mathrm{Y} 2}, \mathrm{~T}_{1}, \mathrm{~T}_{2}\right) \mathrm{T}_{1}=\mathrm{T}_{2}=0\right\} \text { and } \mathrm{p}\left(\mathrm{Z}_{\mathrm{Y} 1}, \mathrm{Z}_{\mathrm{Y} 2}\right) \equiv\left\{\mathrm{p}\left(\mathrm{Z}_{\mathrm{Y} 1}, \mathrm{Z}_{\mathrm{Y} 2}, \mathrm{~T}_{1}, \mathrm{~T}_{\mathrm{x}}\right) \mid \mathrm{T}_{1}=\mathrm{T}_{2}=0\right\} \text {. }
$$


Let $\mathrm{V}^{\mathrm{jD}}$ represent the level of per capita utility obtained in region $\mathrm{j}$ in the decentralized policy equilibrium. Since the developed region is wealthier than the developing region, we observe $\mathrm{V}^{\mathrm{DD}}>\mathrm{V}^{2 \mathrm{D}}$.

\subsection{The International Scheme}

There are three players in our proposed international scheme: the regional regulators and the GEF. The regulators are free to choose their own environmental policies. The GEF is in charge of implementing resource transfers. This agency lacks political and economical powers to directly punish or reward the regulators for their actions. We postulate that the GEF's objective function obeys a proportional equity principle whereby the status quo proportion of regional per capita utility levels is kept constant. This function is described below. The GEF chooses the amount of the interregional transfer in order to maximize its objective function after the regulators make their choices.

The international scheme comes to existence, however, only if both regions voluntarily decide to participate in such a scheme. Let $\mathrm{V}^{\text {js }}$ denote the per capita utility level obtained by region $\mathrm{j}$ if it participates in the international scheme. The regulators and the GEF play the following game:

Stage 0: $\quad$ Each regulator decides whether or not to participate, taking each other's decision as given. Regulator $j$ participates only if $\mathrm{V}^{\mathrm{js}} \geq \mathrm{V}^{\mathrm{j} D}, j=1,2$. The regulators play the "Proportional Equity Game" below if they choose to participate. Otherwise, the game ends and each region gets its reservation utility level.

\section{The Proportional Equity Game}

Stage 1: Taking $\left\{Z_{Y_{2}}\right\}$ as given, regulator 1 chooses non-positive $\left\{Z_{y_{1}}\right\}$ to maximize $\mathrm{V}^{1}\left(\mathrm{p}, \mathrm{Z}_{\mathrm{Y} 1}, \mathrm{Z}_{\mathrm{Y} 2}, \mathrm{~T}_{1}\right)$ s.t. $\mathrm{p}=\mathrm{p}\left(\mathrm{Z}_{\mathrm{Y} 1}, \mathrm{Z}_{\mathrm{Y} 2}, \mathrm{~T}_{1}, \mathrm{~T}_{2}\right)$ and $\mathrm{T}_{1}=\mathrm{T}_{1}\left(\mathrm{Z}_{\mathrm{Y} 1}, \mathrm{Z}_{\mathrm{Y} 2}\right)$. Similarly, regulator 2 
takes $\left\{Z_{\mathrm{Y}_{1}}\right\}$ as given and chooses non-positive $\left\{\mathrm{Z}_{\mathrm{Y}_{2}}\right\}$ to maximize $\mathrm{V}^{2}\left(\mathrm{p}, \mathrm{Z}_{\mathrm{Y} 1}, \mathrm{Z}_{\mathrm{Y} 2}, \mathrm{~T}_{1}\right)$

s.t. $\mathrm{p}=\mathrm{p}\left(\mathrm{Z}_{\mathrm{Y} 1}, \mathrm{Z}_{\mathrm{Y} 2}, \mathrm{~T}_{1}, \mathrm{~T}_{2}\right)$ and $\mathrm{T}_{2}=\mathrm{T}_{2}\left(\mathrm{Z}_{\mathrm{Y} 1}, \mathrm{Z}_{\mathrm{Y} 2}\right)$.

Stage 2: Having observed $\left\{\mathrm{Z}_{\mathrm{Y}_{1}}, \mathrm{Z}_{\mathrm{Y}_{2}}\right\}$, the GEF chooses $\left\{\mathrm{T}_{1}, \mathrm{~T}_{2}\right\}$ to maximize

$$
\operatorname{Min}\left\{\frac{\mathrm{V}^{1}\left(\mathrm{p}, \mathrm{Z}_{\mathrm{Y} 1}, \mathrm{Z}_{\mathrm{Y}}, \mathrm{T}_{1}\right)}{\mathrm{V}^{1 \mathrm{D}}}, \frac{\mathrm{V}^{2}\left(\mathrm{p}, \mathrm{Z}_{\mathrm{Y}}, \mathrm{Z}_{\mathrm{Y}}, \mathrm{T}_{2}\right)}{\mathrm{V}^{2 \mathrm{D}}}\right\} \text { s.t. } \sum_{\mathrm{j}} \mathrm{T}_{\mathrm{j}}=0 \text { and } \mathrm{p}=\mathrm{p}\left(\mathrm{Z}_{\mathrm{Y} 1}, \mathrm{Z}_{\mathrm{Y}}, \mathrm{T}_{1}, \mathrm{~T}_{2}\right) \text {. }
$$

Stage 0 is a "pre-game" stage. The regulators decide whether or not to play the Proportional Equity Game ("PEG" hereafter) in full knowledge of the potential gains from participation. The PEG consists of two stages. The regulators are Stackelberg leaders and the GEF is a common Stackelberg follower. The leaders anticipate the responses of the GEF when they select their most desirable environmental policies. The GEF observes the leaders' choices and makes its own choices. The equilibrium concept used for the PEG is subgame perfection.

In the second stage of the PEG, the GEF's best-response functions, $\mathrm{T}_{\mathrm{j}}\left(\mathrm{Z}_{\mathrm{Y} 1}, \mathrm{Z}_{\mathrm{Y} 2}\right), j=1,2$, satisfy:

$$
\begin{aligned}
& \frac{\mathrm{V}^{1}\left(\mathrm{p}\left(\mathrm{Z}_{\mathrm{Y} 1}, \mathrm{Z}_{\mathrm{Y} 2}, \mathrm{~T}_{1}\left(\mathrm{Z}_{\mathrm{Y} 1}, \mathrm{Z}_{\mathrm{Y} 2}\right), \mathrm{T}_{2}\left(\mathrm{Z}_{\mathrm{Y} 1}, \mathrm{Z}_{\mathrm{Y} 2}\right)\right), \mathrm{Z}_{\mathrm{Y} 1}, \mathrm{Z}_{\mathrm{Y} 2}, \mathrm{~T}_{1}\left(\mathrm{Z}_{\mathrm{Y} 1}, \mathrm{Z}_{\mathrm{Y} 2}\right)\right)}{\mathrm{V}^{\mathrm{ID}}} \\
& =\frac{\mathrm{V}^{2}\left(\mathrm{p}\left(\mathrm{Z}_{\mathrm{Y} 1}, \mathrm{Z}_{\mathrm{Y} 2}, \mathrm{~T}_{1}\left(\mathrm{Z}_{\mathrm{Y} 1}, \mathrm{Z}_{\mathrm{Y} 2}\right), \mathrm{T}_{2}\left(\mathrm{Z}_{\mathrm{Y}}, \mathrm{Z}_{\mathrm{Y} 2}\right)\right), \mathrm{Z}_{\mathrm{Y} 1}, \mathrm{Z}_{\mathrm{Y}}, \mathrm{T}_{2}\left(\mathrm{Z}_{\mathrm{Y} 1}, \mathrm{Z}_{\mathrm{Y} 2}\right)\right)}{\mathrm{V}^{2 \mathrm{D}}}, \\
& \mathrm{T}_{1}\left(\mathrm{Z}_{\mathrm{Y} 1}, \mathrm{Z}_{\mathrm{Y} 2}\right)+\mathrm{T}_{2}\left(\mathrm{Z}_{\mathrm{Y} 1}, \mathrm{Z}_{\mathrm{Y} 2}\right)=0 \text {. }
\end{aligned}
$$

In the first stage, we obtain the following first order conditions if we assume interior solutions:

$$
\frac{\partial V^{j}}{\partial p} \frac{\partial p}{\partial Z_{Y_{j}}}+\frac{\partial V^{j}}{\partial Z_{Y j}}+\frac{\partial V^{j}}{\partial p}\left(\frac{\partial p}{\partial T_{j}} \frac{\partial T_{j}}{\partial Z_{Y_{j}}}+\frac{\partial p}{\partial T_{-j}} \frac{\partial T_{-j}}{\partial Z_{Y_{j}}}\right)+\frac{\partial V^{j}}{\partial T_{j}} \frac{\partial T_{j}}{\partial Z_{Y_{j}}}=0, j=1,2
$$

Given (8), differentiation of (7a) and (7b) yields:

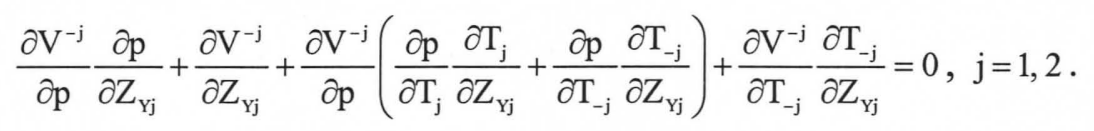




$$
\sum_{i=1}^{2} \frac{\partial T_{i}}{\partial Z_{Y_{j}}}=0, \quad j=1,2
$$

For $j=1,2$, if we use (3a) - (3d), we may rewrite (8) and (9a), respectively, as follows:

$$
\begin{aligned}
& \left(X_{j}^{0}+X_{j}+Z_{X_{j}}-n_{j} X_{j}\right)\left(\frac{\partial p}{\partial Z_{Y j}}+\frac{\partial p}{\partial T_{j}} \frac{\partial T_{j}}{\partial Z_{Y j}}+\frac{\partial p}{\partial T_{-j}} \frac{\partial T_{-j}}{\partial Z_{Y j}}\right)+F_{Z}^{j}\left(\frac{U_{x}^{j}}{U_{y}^{j}}+n_{j} \frac{U_{E}^{j}}{U_{y}^{j}}+G_{E}^{j}\right)+1+\frac{\partial T_{j}}{\partial Z_{Y j}}=0, \\
& \left(X_{-j}^{0}+X_{-j}+Z_{X-j}-n_{-j} X_{-j}\right)\left(\frac{\partial p}{\partial Z_{Y j}}+\frac{\partial p}{\partial T_{j}} \frac{\partial T_{j}}{\partial Z_{Y_{j}}}+\frac{\partial p}{\partial T_{-j}} \frac{\partial T_{-j}}{\partial Z_{Y j}}\right)+n_{-j} \frac{U_{E}^{-j}}{U_{y}^{-j}} F_{Z}^{-j}+G_{E}^{-j} F_{Z}^{j}+\frac{\partial T_{-j}}{\partial Z_{Y_{j}}}=0 .
\end{aligned}
$$

Given (9b) and the market clearing condition for the industrial good, adding up (10a) and (10b) yields

$$
F_{z}^{j}\left(\frac{U_{x}^{j}}{U_{y}^{j}}+n_{j} \frac{U_{E}^{j}}{U_{y}^{j}}+G_{E}^{j}\right)+1+n_{-j} \frac{U_{E}^{-j}}{U_{y}^{-j}} F_{z}^{-j}+G_{E}^{-j} F_{z}^{j}=0, j=1,2 .
$$

Since $U_{x}^{1} / U_{y}^{1}=U_{x}^{2} / U_{y}^{2}$, equations (11) imply that $F_{z}^{1}=F_{z}^{2}$. Given this, we may rewrite (11) as follows:

$$
\frac{U_{x}^{j}}{U_{y}^{j}}=-\frac{1}{F_{z}^{j}}-\sum_{i=1}^{2}\left(n_{i} \frac{U_{E}^{i}}{U_{y}^{i}}+G_{E}^{i}\right), j=1,2 .
$$

Equations (12) inform us that the regional regulators behave efficiently since their regulations fully account for all external effects and do not distort the international terms of trade. The GEF's income transfer functions are powerful enough to nullify the incentives of both regulators of behaving inefficiently. The transfer functions induce both regulators to face the "correct" price for the industrial good.

Given equations (7) and (12), it is straightforward to show that the resulting equilibrium for the global economy is Pareto efficient. Besides and (7) and (12), the global equilibrium allocation satisfies the market clearing condition for the industrial good and the marginal conditions that characterize the behaviors of agricultural producers and consumers. Hence, we obtain: 
Theorem 1: Assume that both regions participate in the international scheme based on proportional equity. Then, the resulting equilibrium for the global economy is Pareto efficient.

Theorem 1 is good news for policymakers who wish to design an international scheme to efficiently control global carbon dioxide emissions. The information provided by Theorem 1 is only "good" news rather than "excellent" news because the result holds only if both regions participate. However, as the result below demonstrates, our proposed international scheme will always induce full participation.

Theorem 2: The equilibrium for the PEG yields $V^{\mathrm{js}}>\mathrm{V}^{\mathrm{j} \mathrm{p}}, j=1,2$.

Proof. We know that $\sum_{\mathrm{j}=1}^{2} \mathrm{~V}^{\mathrm{js}}>\sum_{\mathrm{j}=1}^{2} \mathrm{~V}^{\mathrm{jD}}$ because the equilibrium for the global economy is Pareto efficient. Hence, $V^{1 D}\left(V^{15} / V^{1 D}\right)+V^{2 D}\left(V^{2 s} / V^{2 D}\right)>V^{1 D}+V^{2 D}$. Since $\left(V^{15} / V^{1 D}\right)=\left(V^{2 S} / V^{2 D}\right)$ from $(7 a)$, we have $\left(\mathrm{V}^{1 \mathrm{D}}+\mathrm{V}^{2 \mathrm{D}}\right)\left(\mathrm{V}^{1 \mathrm{~S}} / \mathrm{V}^{1 \mathrm{D}}\right)>\mathrm{V}^{1 \mathrm{D}}+\mathrm{V}^{2 \mathrm{D}}$ or $\mathrm{V}^{1 \mathrm{~S}}>\mathrm{V}^{1 \mathrm{D}}$. A similar reasoning proves that $\mathrm{V}^{2 \mathrm{~S}}>\mathrm{V}^{2 \mathrm{D}}$.

Hence, the news turns out to be excellent! Since the equilibrium for the PEG satisfies both efficiency and individual rationality, the proposed international scheme yields a "win-win" scenario. Intuitively, the "win-win" scenario emerges because the proportional equity principle aligns the incentives of both regions. The GEF's optimal strategy implies that the welfare of the developed region rises if and only if the welfare of the developing region rises. Knowing this, the regulators make efficient choices. In fact, it is easy to show that this "perfect incentive equivalence" phenomenon occurs whenever the GEF's preferences can represented by a function $\operatorname{Min}\left\{\mathrm{w}^{1} \mathrm{~V}^{1}, \mathrm{w}^{2} \mathrm{~V}^{2}\right\}$, where $\mathrm{w}^{1}$ and $\mathrm{w}^{2}$ are positive weights.

\section{Conclusion}

Our results suggest that developed and developing regions may behave efficiently in the presence of an international scheme in which resource transfers from developed to developing 
regions are implemented to satisfy a proportional equity principle. Such transfers promote perfect incentive equivalence since regional welfare levels become complements: the welfare of the developed region can rise if and only if the welfare of the developing region rises. In addition to perfect incentive equivalence, our proposed international scheme always induces both developed and developing regions to participate; that is, it yields a "win-win" scenario. The efficiency and individual rationality properties of such international scheme are especially noteworthy in light of the call for international transfers in the Kyoto Protocol.

We claim that our results are robust to regional policy decentralization provided that the structure of our proposed international scheme remains intact. It is straightforward to show that, as long as the GEF implements the interregional transfer in order to satisfy the proportional equity principle after the regional authorities choose their environmental policies, the results of our analysis would remain unchanged in either a setting where the regulators controlled Pigouvian taxes or a setting where the regulators controlled the regional quantities of carbon dioxide permits and later distributed these quantities to regional agents who could freely trade them in a market. Essentially, the reason is that the complementarity of regional welfare levels, which provides the rationale for our results, would still be present in these alternative and more complex economic settings.

\section{References}

Boadway, R. (1982). On the method of taxation and the provision of local public goods: comment. American Economic Review 72: 846-851.

Chichilnisky, G., G. Heal and D. Starrett (2000). Equity and efficiency in environmental markets: global trade in carbon dioxide emissions. In: Environmental Markets: Equity and Efficiency, G. Chilchinisky and G. Heal (eds.), Columbia University Press, New York. 
Caplan, A.J. and E.C.D. Silva (1999). Federal acid rain games. Journal of Urban Economics 46: 25-52.

Myers, G.M. (1990). Optimality, free mobility, and the regional authority in a federation. Journal of Public Economics 43: 107-121.

Nagase, Y. and E.C.D. Silva (2000). Optimal control of acid rain in a federation with decentralized leadership and information. Journal of Environmental Economics and Management 40: 164-180.

Silva, E.C.D. (1997). Decentralized and efficient control of transboundary pollution in federal systems. Journal of Environmental Economics and Management 32: 95-108.

Silva, E.C.D. and A.J. Caplan (1997). Transboundary pollution control in federal systems. Journal of Environmental Economics and Management 34: 173-186.

Wellisch, D. (1994). Interregional spillovers in the presence of perfect and imperfect household mobility. Journal of Public Economics 55: 167-184. 